\title{
Krystyna Jędralska, Jolanta Bernais, Uniwersytet w perspek- tywie kształcenia przez całe życie, Wydawnictwo Uniwersytetu Ekonomicznego w Katowicach, Katowice 2015, ss. 285.
}

Problematyka kształcenia przez całe życie w kontekście akademickim w ujęciu teoretycznym, jak i praktycznym, podejmowana jest stosunkowo rzadko*. Zwykle bada się ideę LLL i jej realizację na różnych poziomach kształcenia** lub podejmuje temat znaczenia i zmiany roli współczesnego uniwersytetu. Prezentowana publikacja pt. Uniwersytet $w$ perspektywie kształcenia przez całe życie łączy oba tematy, dodatkowo włączając w zakres studiów nad szkolnictwem wyższym (HES - Higher Education Studies) perspektywę nauk ekonomicznych i o zarządzaniu.

Publikacja Uniwersytet $w$ perspektywie kształcenia przez całe życie jest monografią, która ukazała się w 2015 r. i jest pokłosiem VI Wydziałowej Konferencji Dydaktyczno-Naukowej zorganizowanej przez Wydział Zarządzania Uniwersytetu Ekonomicznego w Katowicach. Redaktorki tomu - Krystyna Jędralska i Jolanta Bernais - we wprowadzającym w tematykę książki Wstępie określają sposób rozumienia roli współczesnego uniwersytetu. Piszą tam: „Jeśli przyjmujemy, że wiedza jest obecnie jednym z najważniejszych warunków rozwoju społecznego i istotnym elementem dobra publicznego, to zadaniem uniwersytetu jest zapewnienie stałej oraz powszechnej dostępności do niej na każdym etapie życia i rozwoju człowieka" (s. 7). Tak sformułowane wstępne założenie powoduje, że rozszerza się zakres zadań i funk-

* Tematyka staje się jednak coraz powszechniejsza w związku z wprowadzonymi reformami KRK czy działań PKA, np. publikacja Uczenie się przez całe życie a dydaktyka szkoły wyższej na przykładzie Uniwersytetu Warszawskiego: publikacja pokonferencyjna, M. Kicińska-Habior [et al.], Warszawa 2014.

** Por. E. Solarczyk-Ambrozik (red.) (2013), Całożyciowe uczenie się jako wyzwanie dla teorii i praktyki edukacyjnej, Wydawnictwo Naukowe UAM, Poznań; E. Przybylska (2014), Analfabetyzm funkcjonalny dorostych jako problem społeczny, egzystencjalny i pedagogiczny, Wydawnictwo Naukowe UMK, Toruń; publikacje wydawane cyklicznie, czasopisma: „Dyskursy Młodych Andragogów”, „Edukacja Dorosłych” czy „Rocznik Andragogiczny”. 
cji uniwersytetu, który przestaje być „wieżą z kości słoniowej”, a rozszerza swoją misję. Do dwóch podstawowych zadań uniwersytetu w modelu humboldtowskim, tj. prowadzenia badań naukowych i kształcenia studentów, włącza się dodatkowe zadania wynikające z konieczności współpracy z otoczeniem społecznym, ważnych procesów społecznych (migracje, niż demograficzny, kryzysy finansowe itp.), zmiany roli edukacji i nauki w życiu publicznym. Refleksja nad rozszerzeniem misji uniwersytetu jest w publikacji dość wąsko prowadzona, odwołuje się bowiem do przemian jedynie gospodarczych czy rynkowych (w tyle pozostawiając człowieka, jego potrzeby intelektualne czy duchowe, prospołeczność czy wspólnotowość).

Monografia składa się z trzech części. Każda z nich ma przedstawiać inny punkt widzenia, odmienną perspektywę $\mathrm{w}$ postrzeganiu zadań uniwersytetu w kontekście kształcenia całożyciowego. Dodatkowo teksty często wzbogacone są lub wręcz bazują na doświadczeniach uczelni reprezentowanych przez autorów w prowadzeniu różnych form kształcenia przez całe życie. Jak piszą redaktorki, pierwsza część publikacji zatytułowana Modele ksztatcenia uniwersyteckiego. Doświadczenia i wyzwania zawiera teksty opisujące właśnie doświadczenia z LLL traktowane też jako swoiste wyzwania stające przed uczelniami, będącymi już nie tylko szkołami wyższymi, ale instytucjami przedsiębiorczymi** ${ }^{*}$. By sprostać owym wyzwaniom, należy mieć na względzie to, że „Tworzenie oraz wdrażanie innowacji edukacyjnych powinno odbywać się w ścisłej współpracy świata akademickiego ze światem biznesu" (s. 8).

Druga część monografii pt. Tendencje rozwojowe uniwersytetu. Perspektywa multidyscyplinarna jest zaś wielowątkową dyskusją nad tendencjami rozwojowymi uczelni w dobie cywilizacyjnych przemian społecznych. Multidyscyplinarna perspektywa badawcza jest w tym miejscu wykorzystywana do uwypuklenia jak często w rozważaniach dotyczących szkolnictwa wyższego dominuje spojrzenie ekonomiczne, finansowe, wprowadzające neoliberalne pojęcia, niszczące takie wartości, jak: etos nauki, kodeks etyczny badacza czy autoteliczność nauki. Uczenie (się) staje się działaniem o charakterze utylitarnym, zdominowanym przez zjawisko masowości, utowarowenia wiedzy czy innowacyjności rozumianej nie jako wolność myślenia, ale merkantylność. Być może takie rozumienie i odczytywanie zjawisk wokół uniwersytetu jest dziś dominujące, bowiem, jak piszą redaktorki: „Realizacja misji

* Por. A. M. Kola, K. Leja, Rozszerzona trzecia misja uniwersytetu na przykładzie jego relacji z podmiotami trzeciego sektora, „e-mentor” 2015, nr 4(61), s. 4-12.

** Por. B. R. Clark (1998), Creating entrepreneurial universities: Organizational pathway of transformation, Pergamon, For IAU Press, Oxford. 
kształcenia we współpracy z praktyką i na potrzeby praktyki jest weryfikowana przez rynek pracy" (s. 8). Trzeba jednak zdawać sobie sprawę, że takie stanowisko jest znacznym uproszczeniem, bowiem jest wiele innych wartości, które mogą weryfikować owe sensy, jednak nie zostały one w omawianej publikacji dość wyraźnie wyrażone.

Natomiast ostatnia część publikacji pt. Lifelong learning z perspektywy interesariuszy dotyczy konkretnych, szczegółowych rozwiązań w zakresie LLL, zwłaszcza po wprowadzeniu reformy Krajowych Ram Kwalifikacji. Praktyczność i poglądowość tej części jest znaczącym atutem publikacji, bowiem, jak piszą redaktorki, „Nie umilkły jeszcze spory o zasadność formalizacji procesu kształcenia, zatem pierwsze doświadczenia praktyczne nabierają istotnej wartości jako informacja zwrotna formułowana przez środowisko akademickie" (s. 9).

Najwięcej tekstów autorskich znajduje się w części pierwszej dotyczącej modeli kształcenia uniwersyteckiego w zakresie LLL*. Zawartych jest tu dziewięć tekstów o różnym stopniu ogólności/szczegółowości. Niektóre $\mathrm{z}$ nich bowiem opisują konkretne doświadczenia $\mathrm{z}$ wdrażania idei LLL w jednostkach, inne zaś podejmują temat ogólny - związany z rolą uniwersytetu we współczesnym społeczeństwie (Rola uniwersytetów we wspótczesnej gospodarce opartej na wiedzy autorstwa Anny Kwiecień).

Sławomir Smyczek pisze w swoim tekście pt. Wdrażanie i rozwój koncepcji kształcenia przez całe życie na Uniwersytecie Ekonomicznym w Katowicach o różnych formach kształcenia ekonomicznego prowadzonych na uczelni dla odmiennych grup wiekowych („grup docelowych”, s. 17) - uczniów szkół podstawowych, gimnazjów, liceów i techników, a także dla seniorów. Uczelnia oferuje też studia podyplomowe, doktoranckie, ale też kursy, szkolenia czy warsztaty dla osób pracujących. Jak pisze autor, tak szeroka działalność mieści się w dziesięciu obszarach rekomendacji wypracowanych w ramach seminarium European University Association dokumentu The European Universities' Charter on Lifelong Learning. Co ważne, autor wskazuje też na słabe strony kształcenia LLL na UE w Katowicach, traktując swoje uwagi jako zadania, nad którymi należy pracować.

Podobny charakter mają dwa następne teksty Janusza Marka Lichtarskiego i Jerzego Niemczyka: Organizacja ksztatcenia ustawicznego na uczelniach wyższych - modele i doświadczenia praktyczne oraz Agnieszki Sitko-Lu-

* Niestety ten zakres problemowy nie jest zawarty w tytule, co jest nieścisłością i może powodować niezrozumienie. Dla badaczy uniwersytetu kategoria „modeli kształcenia uniwersyteckiego" łączy się z konkretnymi zadaniami, ale i swoistą filozofią działania. W publikacji określenie to jest zatem zbyt szerokie. 
tek, Anny Rakowskiej oraz Zbigniewa Pastuszaka: Synergia nauki i biznesu w perspektywie kształcenia przez całe życie na przykładzie Wydziału Ekonomicznego UMCS. Pierwszy z nich omawia rozwój kształcenia ustawicznego na Uniwersytecie Ekonomicznym we Wrocławiu, analizując ten proces w teoretycznym kontekście istnienia różnych modeli kształcenia LLL (scentralizowanego, rozproszonego, hybrydowego). Drugi natomiast włącza do prezentacji dobrych praktyk kategorię „synergii”, użytą w zrealizowanym projekcie UMCS, nagradzanym przez MNiSW oraz NCBiR.

Finansową perspektywę do analiz wprowadza natomiast tekst Józefa Dziechciarza O pomiarze efektywności nakładów na edukację i szkolenia w kontekście kształcenia przez całe życie. Autor korzysta tu z wiedzy z zakresu nauk o zarządzaniu i proponuje różnorodne systemy mierzenia efektywności nakładów na szkolenia i treningi, jakie odbywają się na uczelniach.

Natomiast perspektywa porównawcza została przyjęta w tekstach Radosława Jeża, Jacka Szołtyska, Sebastiana Twaroga i Svetlany Karstiny Mobilność edukacyjna studentów Polski i Kazachstanu - studium porównawcze oraz Urszuli Grzegi - Kształcenie ustawiczne w Polsce i Unii Europejskiej oraz formy aktywności edukacyjnej dorosłych Polaków. Oba teksty prezentują niezwykle interesujące dane dotyczące motywacji i poziomu podejmowania kształcenia przez obywateli różnych krajów. Badacze prezentują wyniki badań nad mobilnością międzynarodową, ale też różnic w korzystaniu z dodatkowych form edukacji.

Dla osób zajmujących się edukacją i dydaktyką szkoły wyższej mogą okazać się interesujące dwa teksty o charakterze metodycznym. Katarzyna Rupik i Justyna Maciąg w opracowaniu pt. Aktywne metody kształcenia we wspótpracy z otoczeniem gospodarczym - doświadczenia i rekomendacje prezentują zrealizowane projekty konsultingu studenckiego, wskazując na korzyści i ograniczenia metody. Natomiast Patrycja Klimas podejmuje w tekście pt. Nowe media a skuteczność procesów kształcenia - perspektywa studentów Uniwersytetu Ekonomicznego w Katowicach problem nowoczesnych technologii wykorzystywanych przez uczelnie w celach edukacyjnych.

Część druga monografii pt. Tendencje rozwojowe uniwersytetu. Perspektywa multidyscyplinarna zawiera osiem tekstów o zróżnicowanej tematyce, które często przedstawiają jedynie teoretyczną perspektywę (nie zawsze, niestety, nawiązując wprost do idei całożyciowego uczenia się).

Wojciech Czakon w artykule pt. Od humanizmu do kariery. Zmiany uniwersytetu dziś $i$ jutro pokazuje wyzwania, jakie stoją obecnie przed uniwersytetami. Przywołuje także wielowątkową tradycję i historię tej instytucji, która coraz częściej ulega wpływom niekorzystnych "trendów i presji” 
(s. 107): umasowienia, standaryzacji i utowarowienia. „Humanistyczne” podejście reprezentuje Aleksandra Pethe w tekście Okiem humanisty: O horyzontach uniwersyteckiego dialogu między humanistykq a ekonomiq. Artykuł stanowi ważny w tomie głos w dyskusji, przywołujący istotność i konieczność włączania do nauk ekonomicznych myślenia humanistycznego. Wychodzi poza współczesne tendencje uczynienia z uniwersytetu instytucji przedsiębiorczej, „fabryki dyplomów”, gdzie studenci są tylko klientami kupującymi usługę edukacyjną. Kolejnym przykładem takiego myślenia jest tekst Anny Piekacz i Pauliny Kuzior Realizacja zadań rozwojowych w perspektywie ksztatcenia ustawicznego. Autorki postawiły sobie ambitne zadanie powiązania teorii zadań rozwojowych Roberta Havinghursta z ideą LLL.

Tekst Grażyny Musiał i Eugeniusza Kośmickiego - Rozwój nauki od wyjaśniania do jej instrumentalizacji jest próbą pokazania rozwoju nauki z metodologicznego punktu widzenia, jednak bez wyraźnych odniesień do zadań i roli LLL.

Grażyna Trzpiot w opracowaniu Nowe zadania dla zapewnienia jakości kształcenia $w$ szkolnictwie wyższym analizuje zaś uwarunkowania i wyniki różnych modeli zarządzania i organizowania uczelni w kontekście zapewnienia jakości kształcenia. Jest to wciąż aktualny problem szkolnictwa wyższego, dlatego warto przedstawiać różne aspekty, korzystając z dorobku różnych dyscyplin.

Artykuł Rola uniwersytetów w budowaniu społeczeństwa informacyjnego autorstwa Ewy Ziemby, Tomasza Papaja i Marii Jadamus-Hacury omawia autorskie badania dotyczące stosowania systemów informatycznych (ICTs information and communication technologies) przez różne, charakteryzowane za pomocą kategorii socjologicznych, grupy wiekowe, tzn. „pokolenia” (pokolenie X, Y, Baby Boomers itp.). Autorzy podsumowują treści zawarte w tekście w klarownej tabeli, wskazującej na znaczącą rolę uniwersytetu w doskonaleniu stosowania ICTs przez pokolenia (s. 160-161), gwarantującą rozwój form całożyciowego uczenia się.

Dwa ostatnie teksty tej części monografii podejmują interdyscyplinarny problem zrównoważonego rozwoju. Elżbieta Lorek w opracowaniu pt. Zrównoważona konsumpcja i produkcja - wyzwania dla edukacji w polskim szkolnictwie wyższym. Problemy i doświadczenia oraz Arnold Pabian w tekście pt. Zrównoważony uniwersytet - zasoby $i$ zasady $w$ obszarze sustainability podejmują niecodzienne w HES tematy, jakim jest dbanie jednocześnie o rozwój i dobrostan społeczny, gospodarczy i ekologiczny. Widać w tym potencjał badawczy dla idei LLL, jednak nie został on w pełni uwypuklony przez autorów. 
Część trzecia publikacji pt. Lifelong learning z perspektywy interesariuszy zawiera siedem tekstów prezentujących tzw. „dobre praktyki” w zakresie LLL na uczelniach. Znalazły się one w tym miejscu (a nie w części pierwszej, która też prezentuje konkretne rozwiązania), ponieważ przedstawiają problemy związane z kształceniem całożyciowym dotyczące poszczególnych grup biorących udział w tym procesie: nauczycieli akademickich, pracodawców, studentów, samorządów.

Artykuł pt. Ścieżka rozwoju i stałego doskonalenia kariery zawodowej logistyka - model Katedry Logistyki Ekonomicznej na UE w Katowicach ma wielu autorów: Danutę Kisperską-Moroń, Ryszarda Pinieckiego, Piotra Hanusa, Dagmarę Jarosz-Lewandowską, Krzysztofa Niestroja, Edytę Klosę, Marka Kasperka, Marcina Świtałę i Krzysztofa Zowadę. Prezentują oni wieloaspektowy obraz kształcenia w zawodzie logistyka, począwszy od pobudzania zainteresowań uczniów szkół podstawowych i gimnazjów, organizowanie studiów podyplomowych i kursów doskonalących, aż do dbania o warunki uprawiania tego zawodu (np. postulując automatyzację i wprowadzanie nowoczesnych technologii).

Grzegorz Głód i Jacek Pietrucha w tekście pt. Praktyczny profil studiów na kierunku Przedsiębiorczość i Finanse - pierwsze doświadczenia i nowe wyzwania omawiają kwestię wciąż jeszcze niepopularnych i rzadkich modeli kształcenia praktycznego na uczelniach. Autorzy odwołują się do uwarunkowań prawnych wykonywania zawodu, zapewnienia jakości w tego typu edukacji, ale też podejmują dylemat kształcenia praktycznego w warunkach uniwersyteckich. Problemu tego dotyka też opracowanie Barbary Czarneckiej i Małgorzaty Pańkowskiej pt. Praktyka jako środowisko propagowania efektów kształcenia. Autorki analizują znaczenia praktyk i sposób ich organizacji, by faktycznie podnosiły poziom kompetencji absolwentów i były korzystne dla pracodawców.

Natomiast Agnieszka Dziubińska i Iwona Woźniak w erudycyjnym artykule Koncepcja Lifelong Learning z perspektywy nauczyciela akademickiego wprowadzają pojęcia społeczeństwa wiedzy, autonomii uniwersytetów, prorynkowej orientacji kształcenia w kontekst kształcenia nauczycieli akademickich. Ważne jest, by mieć świadomość przemian społecznych i gospodarczych warunkujących proces edukacji. Drugą stronę tego problemu przedstawia tekst Marcina Komańdy pt. Formy ksztatcenia a studia i praca zawodowa w opinii absolwentów kierunku Zarzqdzanie na Uniwersytecie Ekonomicznym $w$ Katowicach. Autor zbadał dwie główne kwestie: (1) opinie na temat kształcenia w kontekście rozwoju zawodowego i możliwości na ryn- 
ku pracy absolwentów, (2) opinie na temat „spostrzegania okresu pracy zawodowej jako możliwości realizacji określonych form kształcenia” (s. 234).

W opracowaniu Kingi Hoffmann i Moniki Rutkowska pt. Modele kooperacji uczelni z biznesem znalazły się interesujące uwagi na temat korzyści wynikających ze współpracy uczelni z otoczeniem gospodarczym (s. 248). Autorki omawiają także badania przeprowadzone wśród studentów dotyczące studiowania i współpracy uczelni z biznesem.

Tom zamyka tekst Zygmunta Kruczka pt. Problem uznawania efektów kształcenia uzyskanych $w$ systemach pozaformalnych na turystycznych kierunkach kształcenia. Autor charakteryzuje wciąż rzadko podejmowany problem uznawalności innych niż uniwersyteckie doświadczenia edukacyjne w świetle przepisów prawa.

Podsumowując, należy stwierdzić, że najmocniejszą stroną publikacji jest praktyczny (ale nie metodyczny) charakter zawartych w niej tekstów. Autorzy zaprezentowali „dobre praktyki”, tworząc swoiste forum wymiany doświadczeń. Jest to nieoceniona pomoc w pracy akademickiej, zwykle realizowanej nie przez jednostki administracyjne, ale pracowników naukowych (mam tu na myśli np. przygotowanie programu studiów czy organizacja praktyk). Zawarte tu teksty są nie tylko źródłem wiedzy o tym, jak i kogo kształcić, ale pomagają zrozumieć, dlaczego należy zmienić systemy czy modele kształcenia tak, by podnosić jakość edukacji. Zabrakło być może elementu kształtowania określonych postaw i budowania etosu pracy czy przedsiębiorczości, autorzy bowiem skupili się na samym procesie kształcenia.

Uwagi i sugestie miałabym natomiast do samej redakcji tekstów i ich porządku w tomie. W publikacji brało udział bardzo wielu autorów, choć z jakiegoś powodu ich nazwiska nie są eksponowane przy tytułach rozdziałów w samym tekście. Nie ułatwia to lektury czytelnikowi i stawia pytania o celowość tego pomysłu. Powstaje także inna wątpliwość - kto jest odbiorcą tej publikacji? Całość na pewno porządkuje wiedzę, daje wskazówki z zakresie praktyki kształcenia. Zwraca to uwagę na fakt, że doradztwa w zakresie dbania o jakość kształcenia potrzebują nie tylko studenci, pracodawcy czy absolwenci, ale też nauczyciele akademiccy. 